\title{
Młode osoby a sytuacja na rynku pracy w województwie podkarpackim
}

\section{Young people and the situation on the labour market in the Podkarpackie Voivodeship (Poland)}

\begin{abstract}
Streszczenie: Wobec młodych osób, dokonujących tranzycji z systemu edukacji do rynku pracy, odnotowuje się mniej korzystne wartości wskaźników zatrudnienia i stopy bezrobocia niż w odniesieniu do osób niemłodych. Wynika to zwłaszcza z braku doświadczenia, ogólnych umiejętności i specjalistycznej wiedzy, co sprawia, że osoby te są mniej atrakcyjnymi pracownikami. Celem artykułu jest diagnoza i ocena sytuacji młodych osób na rynku pracy w województwie podkarpackim. Realizacja przyjętego celu wymagała analizy literatury przedmiotu oraz danych statystycznych. Przeprowadzono również własne badania empiryczne, stanowiące uzupełnienie zasadniczych rozważań. Wyniki przeprowadzonych badań wskazują na zdecydowanie gorszą sytuację młodych osób na rynku pracy w województwie podkarpackim w porównaniu z sytuacją nie tylko pozostałych grup, lecz również pozostałych województw. Jednocześnie, biorąc pod uwagę wymagania regionalnego rynku pracy, badane młode osoby nie oceniły wysoko swoich przedsiębiorczych umiejętności i motywacji do podjęcia działania. Wśród rekomendowanych rozwiązań przyczyniających się do poprawy sytuacji charakteryzowanej grupy wymienić należy szkolenia, obejmujące treści zgłaszane przez pracodawców, monitoring losów absolwentów w celu dostosowania programu kształcenia do potrzeb rynku pracy oraz wsparcie udzielane młodym pracownikom przez przełożonych.
\end{abstract}

\begin{abstract}
The employment and unemployment rates are less favourable for young people who make a transition from the education system to the labour market than for non-young people. It is the lack of experience, general skills and specialised knowledge which makes them less attractive as employees. The aim of the study is to diagnose and assess the situation of young people on the labour market in the Podkarpackie Voivodeship (Poland). The literature review and analysis of the statistical data were used to achieve the goal. Own empirical research was also carried out, complementing the basic considerations. The results of the conducted research definitely indicate a worse situation of young people on the labour market in the Podkarpackie Voivodeship compared to the situation not only of other groups, but also compared to other voivodeships. At the same time, the surveyed young people do not satisfyingly assess their entrepreneurial skills and motivation of needs, taking into account the requirements of the
\end{abstract}


regional labour market. Among the recommended solutions contributing to the improvement of the situation of the characterised group, one should mention training, including the content reported by employers, monitoring the fate of graduates in order to adapt the education program to the needs of the labour market, as well as support provided to young employees by their superiors.

Słowa kluczowe: młode osoby; NEET; rynek pracy; województwo podkarpackie

Keywords: labour market; NEET; Podkarpackie Voivodeship; young people

Otrzymano: 30 grudnia 2020

Received: 30 December 2020

Zaakceptowano: 14 maja 2021

Accepted: 14 May 2021

\section{Sugerowana cytacja/Suggested citation:}

Mazurkiewicz, A. (2021). Młode osoby a sytuacja na rynku pracy w województwie podkarpackim. Przedsiębiorczość - Edukacja [Entrepreneurship - Education], 17(1), 49-64. https://doi.org/ $10.24917 / 20833296.171 .4$

\section{Wstęp}

Młode osoby stanowią specyficzną grupę społeczną, gdyż dokonują przejścia z systemu edukacji do życia zawodowego. Ten etap życia jednostki, określany jako „wyłaniająca się dorosłość”, cechuje m.in. brak wykrystalizowania poczucia tożsamości czy wzmożone eksperymentowanie na rynku pracy (Bańka, 2007). Następują w nim istotne zmiany w życiu człowieka. Wyzwaniami są zwłaszcza: poszukiwanie pracy, sprecyzowanie pożądanej ścieżki kariery zawodowej, odkrywanie oczekiwań w nowej roli - roli zawodowej (Mackenzie Davey, Arnold, 2000). Podjęcie pierwszej stałej pracy oddziałuje na dalszą aktywność zawodową jednostki - rozwój zawodowy, karierę, a także na jej rozwój osobowy i życie rodzinne (Wiatrowski, 2009). Ma również znaczenie dla przedsiębiorczości jednostki, jej otwartości na nowe doświadczenia oraz zdolności do samozatrudnienia (Bańka, 2007).

Sytuacja młodych osób na rynku pracy stanowi przedmiot zainteresowania zarówno przedstawicieli nauki, jak i praktyki. Potrzeba rozpatrywania tego zjawiska istnieje ze względu na zdecydowanie mniej korzystne wartości wskaźników dotyczących rynku pracy dla charakteryzowanej grupy w porównaniu $\mathrm{z}$ wynikami dla populacji. Stąd jako cel artykułu przyjęto diagnozę i ocenę sytuacji młodych osób na rynku pracy w województwie podkarpackim. W opracowaniu poszukiwano zwłaszcza odpowiedzi na następujące pytania:

1. Jaka jest sytuacja młodych osób na rynku pracy w województwie podkarpackim w porównaniu z sytuacją osób starszych od nich?

2. Jaka jest sytuacja młodych osób na podkarpackim rynku pracy w porównaniu z sytuacją młodych osób na rynku pracy w pozostałych województwach?

Aby zrealizować cel pracy, przeprowadzono analizę literatury przedmiotu, skorzystano z metody analizy danych statystycznych dotyczących lat 2006-2019 (w określonych przypadkach z innego okresu, co było uzasadnione dostępnością danych). Głównymi źródłami informacji statystycznej były bazy danych i opracowania Głównego Urzędu Statystycznego, w tym BEAL, Urzędu Statystycznego w Rzeszowie, informacje Wojewódzkiego 
Urzędu Pracy w Rzeszowie oraz Eurostat. Przeprowadzono również własne badania empiryczne, stanowiące uzupełnienie zasadniczych rozważań, których wyniki poddano analizie jakościowej.

\section{Pojęcie młodych osób}

Pojęcie młodych osób jest kategorią niejednorodną. Problem ten przekłada się na różne określanie granic wieku, co stwarza implikacje dla dalszych badań. Osoby do 24 roku życia określane są jako młodzież. W tym ujęciu stanowią one:

- kategorię demograficzną, dla której granice wieku określone są przez wiek właściwy dla kończenia szkoły podstawowej, z drugiej strony dla szkoły wyższej i zamykający okres eksploracji zawodowej (15-24 lata),

- kategorię kształcenia, według której młodzież tworzą uczniowie i studenci szkół dziennych (15-24 lata),

- kategorię zatrudnienia, zgodnie z którą młodzież to osoby w wieku 18-24 lata, aktywne zawodowo (tzn. pracujące lub bezrobotne) (Broszkiewicz, 2010).

Progi wieku stanowią podstawę do określenia grupy młodych osób w kontekście rynku pracy. Główny Urząd Statystyczny definiuje tę grupę jako ludność w przedziale 15-34 lata. Tak szerokie ramy wieku powodują niejednorodność i zróżnicowanie grupy nie tylko ze względu na wiek, lecz również ze względu na poziom zdobytego wykształcenia i kontynuowanej edukacji. Część młodych osób aktywizuje się zawodowo podczas praktyk szkolnych, część wchodzi w pełni na rynek pracy po ukończeniu szkoły zawodowej lub średniej, część kontynuuje naukę w szkole wyższej (GUS, 2010). We wskazanej grupie wraz z wiekiem zwiększa się odsetek osób aktywnych zawodowo i zatrudnionych, maleje natomiast udział osób bezrobotnych.

W statystykach powiatowych urzędów pracy kategoria młodych osób odnosi się do osób w wieku od 18 roku życia (wiek uzyskania pełnej zdolności do czynności prawnych) do 30 roku życia (w tym do 25 roku życia - granica ta dotyczy zwłaszcza uczniów i studentów, natomiast wiek 25-30 lat - osób pracujących zawodowo). Z kolei dane dotyczące sytuacji młodych osób na rynku pracy publikowane przez Eurostat obejmują grupę osób w wieku 15-24 lata lub szerzej: 15-29 lat.

W niniejszym opracowaniu przyjęto, że młode osoby należą do grupy wiekowej 15-29 lat. Podkreśla się, że osoby w wieku 30-39 lat stanowią już silną rynkowo kategorię pracobiorców i ich sytuacja na rynku pracy jest korzystniejsza niż sytuacja osób młodszych (Pańków, 2012). Sprecyzowane wyżej granice wiekowe dla grupy młodych osób świadczą o wydłużającym się okresie „dochodzenia do niezależności ekonomicznej i samodzielnego pełnienia ról społecznych” (Broszkiewicz, 2010: 51).

Przyczyny i konsekwencje trudności młodych osób na rynku pracy wyniki badań międzynarodowych

Sytuacja młodych osób na rynku pracy nie jest korzystna; najdobitniej odzwierciedla ją określenie ich mianem straconego pokolenia (lost generation) (FutureLab Europe, 2013). Wobec tej grupy odnotowuje się niskie wskaźniki zatrudnienia i wysokie wskaźniki stopy bezrobocia. Wśród podstawowych przyczyn mniej korzystnej sytuacji młodych osób na rynku pracy wobec ogólnej sytuacji należy wskazać przede wszystkim brak doświadczenia, 
specjalistycznej wiedzy (Braziene, Merkys, Mikutaviciene, 2014) oraz umiejętności ogólnych (Bell, Blanchflower, 2011a), co powoduje, że osoby te są mniej atrakcyjnymi pracownikami z perspektywy pracodawców. Ponadto osoby te wchodzą na rynek pracy po raz pierwszy, stąd ich pozycja jest znacznie mniej korzystna w porównaniu z osobami aktywnymi na tym rynku - zatrudnionymi lub zmieniającymi pracę (Rybicka, 2014). Ze względu na niewielkie doświadczenie zawodowe młode osoby mają nie tylko mniejsze szanse na znalezienie pracy - również ich zatrudnienie odbywa się często na mało korzystnych warunkach (Komisja Europejska, 2020). Uzasadnieniem większego odsetka bezrobotnych wśród młodych osób niż wśród dorosłych mogą być: z perspektywy pracodawcy - konieczność poniesienia zbyt dużych kosztów na przygotowanie tych osób do pracy, nieadekwatna do późniejszych korzyści, a także problemy finansowe przedsiębiorstw prowadzące do zwolnienia w pierwszej kolejności młodych pracowników (Bell, Blanchflower, 2011a). Również niekorzystna sytuacja makroekonomiczna przyczynia się do redukcji zatrudnienia przede wszystkim w tej grupie pracowników (Komisja Europejska, 2020).

Rozbieżność między posiadanymi umiejętnościami a wymaganiami stanowiska pracy oraz wygórowane ambicje i oczekiwania dotyczące warunków pracy stanowią kolejne przesłanki niższych wartości wskaźników zatrudnienia młodych osób. Do ich mniejszej aktywności może przyczyniać się również brak wiedzy o możliwościach poszukiwania pracy, brak wystarczających środków finansów umożliwiających przetrwanie tego okresu, a także brak wsparcia ze strony najbliższych (Jakimiuk, 2017).

Kształtowanie się sytuacji na rynku pracy może prowadzić do rezygnacji przez młode osoby z jakichkolwiek starań mających na celu pozyskanie lub rozwój kwalifikacji czy też zdobycie zatrudnienia. Taka sytuacja zwiększa prawdopodobieństwo wejścia do grupy NEET (ang. not in employment, education or training) - młodych osób, które nie są aktywne na rynku pracy, nie uczestniczą w kształceniu formalnym czy w szkoleniach podnoszących ich kwalifikacje zawodowe. Ze względu na znaczący odsetek należących do tej grupy, zjawisko NEET stało się jednym z ważniejszych problemów społecznych (Krause, 2016).

Trudna sytuacja na rynku pracy ma liczne konsekwencje zarówno dla społeczeństwa, jak i dla młodej osoby oraz jej rodziny. Bezrobocie na początkowym etapie kariery, zwłaszcza długotrwałe, oddziałuje na jej rozwój (Barone, Schizzerotto, 2011). Brak pewności oraz stabilności zatrudnienia uniemożliwia młodym osobom planowanie życia osobistego (Jakimiuk, 2017) oraz staje się powodem pogorszenia sytuacji finansowej (Rybicka, 2014). Bezrobocie powoduje marginalizację społeczną, staje się przyczyną frustracji oraz różnych patologii (Rybicka, 2014), które nasilają się wraz z czasem. Do pozostałych konsekwencji społecznych można zaliczyć m.in.: zahamowanie rozwoju kluczowych cech zwiększających szanse na zatrudnienie (kompetencji miękkich, w tym motywacji, zarządzania czasem i umiejętności komunikowania się), pogorszenie perspektyw demograficznych (opóźnianie decyzji o założeniu rodziny i odwlekanie momentu posiadania dzieci, rezygnację z udziału w społeczeństwie obywatelskim, w tym niższy poziom zaangażowania politycznego, nasilenie emigracji, utratę zdolności socjalnej do adaptacji pracowniczej, zwiększone prawdopodobieństwo angażowania się w aspołeczne zachowania, narastanie napięć i konfliktów z najbliższym otoczeniem, nasilenie przestępczości, zagrożenie bezdomnością, wzrost liczby samobójstw, wcześniejszą umieralność.

Poziom wskaźników zatrudnienia i bezrobocia młodych osób stanowi także konsekwencję sytuacji makroekonomicznej, która jednocześnie oddziałuje na wysokość ich wynagrodzenia w przyszłości (Genda, Kondo, Ohta, 2010), zagrożenie ubóstwem 
i wykluczeniem społecznym (Gallie, Paugam, 2000; Mroz, Savage, 2006) oraz na stan zdrowia fizycznego i psychicznego (Blanchflower, 2010). Długoterminowe skutki negatywnych makroekonomicznych uwarunkowań są charakterystyczne dla młodych osób (Bell, Blanchflower, 2011b; Blanchflower, Oswald, 2011), gdyż grupa ta jest bardziej podatna na negatywne zmiany na rynku pracy (Koptiew, 2014).

\section{Aktywność ekonomiczna młodych osób w województwie podkarpackim}

Zawodową sytuację młodych osób kształtuje w dużym stopniu specyfika regionalnego rynku pracy. Województwo podkarpackie cechuje stosunkowo młody wiek ludności (w 2019 r. mediana wieku wyniosła 40,3 lat, tj. rok mniej niż dla kraju) oraz kształtujący się korzystniej niż przeciętnie w kraju przyrost naturalny - w pierwszym półroczu $2020 \mathrm{r}$. wyniósł on -0,2 na 1 tys. ludności wobec średniej dla kraju -1,6. Jeszcze w roku poprzedzającym w województwie odnotowano dodatni przyrost naturalny na poziomie 0,27 , wobec ujemnej średniej dla kraju -0,91, co oznacza, że na koniec pierwszego półrocza 2020 r. liczba ludności zmniejszyła się w porównaniu z poprzednim okresem.

Województwo ma rolniczo-przemysłowy charakter - charakteryzuje je największy w skali kraju odsetek ludności zamieszkującej na wsi (58,6\%). Cechuje je niekorzystna dla pracownika sytuacja na rynku pracy: stopa bezrobocia w październiku 2020 r. wyniosła 8,9\% i była wyższa o 2,8 pp. od średniej dla kraju, natomiast przeciętne miesięczne wynagrodzenie w sektorze przedsiębiorstw w maju 2020 r. wyniosło 4185,74 zł i było o 934,20 zł niższe niż średnio w Polsce. Dodatkowo należy zaakcentować słabą pozycję Podkarpacia, uwzględniając poziom $\mathrm{PKB}$, będącego miernikiem odzwierciedlającym możliwości gospodarcze regionu - PKB na 1 mieszkańca w 2017 r. wyniósł 36088 zł, co stanowiło zaledwie 69,7\% średniej dla kraju i oznaczało przedostatnią pozycję wśród wszystkich województw.

Pozytywnie należy ocenić bilans demograficzny wynikający z przywiązania do miejsca zamieszkania. Dostrzega się również powstawanie i dynamiczny rozwój małych i średnich przedsiębiorstw, co stanowi zaletę podkarpackiego rynku pracy i umożliwia wykorzystanie dostępnego potencjału ludzkiego.

Mimo tych możliwości zdecydowana większość młodych osób sytuację na rynku pracy oceniła negatywnie („zdecydowanie zła” - 62\% wskazań, „bardzo zła” - 14\%) (Piecuch T., Piecuch M., 2014). Potwierdzenie tych subiektywnych opinii stanowią dane statystyczne. Podstawowymi wskaźnikami zastosowanymi do oceny sytuacji młodych osób na rynku pracy są wskaźniki aktywności zawodowej, zatrudnienia, bezrobocia, liczba ofert na 1 tys. bezrobotnych oraz liczba utworzonych i zlikwidowanych miejsc pracy przypadająca na 1 tys. bezrobotnych osób. Analizie poddano również zjawisko NEET.

Młode osoby na Podkarpaciu są mniej aktywne zawodowo niż osoby niemłode - dotyczy to zaledwie co drugiej osoby w tej grupie. Nie jest to jednak zjawisko nowe - uwzględniając średnie wskaźniki aktywności zawodowej z okresu 2006-2019, odsetek aktywnych zawodowo młodych osób wynosił 46,2\%-53\%. W całym okresie był o 30 pp.-40 pp. niższy niż odsetek osób aktywnych zawodowo w wieku 30-49 lat. Taka sytuacja była charakterystyczna dla całego kraju.

W grupie młodych osób największy odsetek stanowiły osoby bierne zawodowo w analizowanym okresie wprawdzie odsetek ten zmniejszył się z 54\% do 50\%, lecz nadal pozostawał znaczący (rycina 1). Udział pracujących osób po początkowym wzroście z niemal 34\% do prawie 40\% w roku 2008 zaczął spadać i w roku 2013 wyniósł ponownie 
Rycina 1. Struktura osób w wieku 15-29 lat w województwie podkarpackim według kryterium aktywności zawodowej w latach 2006-2019 (w \%)

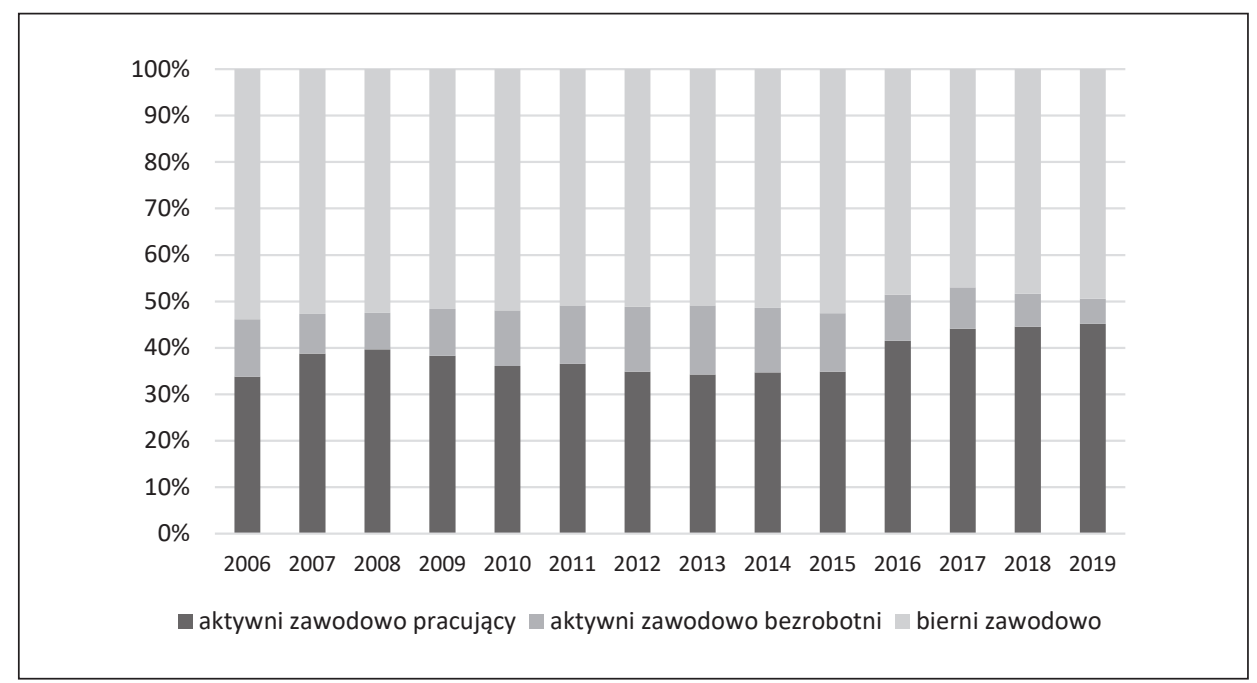

Źródło: opracowanie własne na podstawie: GUS (2020, 8 października)

Rycina 2. Odsetek osób aktywnych zawodowo w wieku 15-29 lat w kraju i województwie podkarpackim w latach 2006-2019

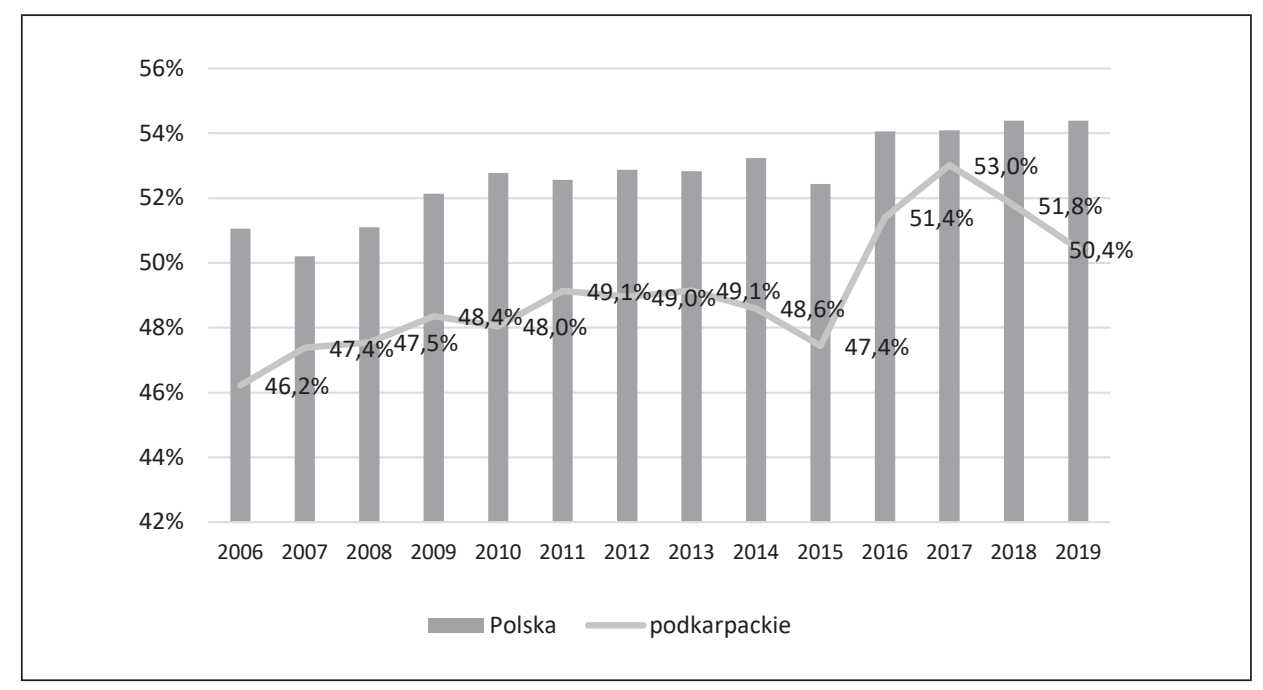

Źródło: opracowanie własne na podstawie: GUS (2020, 8 października)

34\%, po czym wzrósł do 45,33\% w 2019 r. Natomiast odsetek osób bezrobotnych po początkowym spadku z 12,35\% do niemal 8\% wzrósł o 7 pp. w roku 2013, następnie zmniejszył się i w 2019 r. wyniósł 5,38\%. Przedstawione zmiany zachodzące bezpośrednio po 2008 r. stanowiły konsekwencję globalnego kryzysu gospodarczego. Dopiero po upływie pięciu lat zmiany zaczęły być korzystniejsze. 
Młode osoby w województwie podkarpackim są mniej aktywne niż przeciętnie ich rówieśnicy w kraju - w badanym okresie różnica wynosiła 1,1 pp.-5,0 pp., średnio 3,6 pp. (rycina 2). Zmiany w aktywności zawodowej w badanej grupie na poziomie województwa oraz na poziomie krajowym były zbliżone - po początkowym wzroście nastąpiła stabilizacja w aktywności zawodowej, w 2015 r. odnotowano spadek, po czym kolejny wzrost i od 2016 r. utrzymanie się na niemal niezmienionym poziomie w kraju, natomiast na poziomie województwa ostatnie lata ukazały znaczący spadek aktywności zawodowej młodych osób.

Wśród młodych osób aktywnych zawodowo wskaźniki zatrudnienia są zróżnicowane ze względu na wiek, co jest uzasadnione uczestniczeniem przez młodszą grupę w systemie edukacji. Wartość wskaźnika zatrudnienia w grupie 15-24 lata w 2019 r. wyniosła 24,8\%, co ulokowało województwo podkarpackie na ostatniej pozycji wśród wszystkich województw. Wśród mężczyzn zatrudnionych było 31,8\% (przedostatnia pozycja), natomiast wśród kobiet odsetek był najniższy i znacząco odbiegał od średniej w kraju (16,3\% wobec $27,8 \%$ ). Tej negatywnej oceny nie zmieniło poszerzenie przedziału wiekowego o osoby koncentrujące się w większym stopniu na pracy zawodowej - do 29 roku życia - wartość wskaźnika zatrudnienia wynosząca $45,3 \%$ była najniższa w kraju (tabela 1 ) oraz w odniesieniu do kobiet (36,0\% wobec średniej krajowej 44,7\%). W tej grupie również odsetek mężczyzn był mniejszy niż przeciętnie w kraju, jednak różnice nie były już tak znaczące (53,8\% wobec $56,7 \%$ przeciętnie w Polsce).

Tabela 1. Wskaźnik zatrudnienia wśród osób w wieku 15-29 lat w 2019 r. według województw (\%)

\begin{tabular}{|l|c|c|c|}
\hline \multirow{2}{*}{ Wyszczególnienie } & \multicolumn{3}{c|}{ Wskaźnik zatrudnienia } \\
\cline { 2 - 4 } & ogółem & mężczyźni & kobiety \\
\hline Polska & 50,8 & 56,7 & 44,7 \\
\hline dolnośląskie & 53,7 & 57,5 & 49,7 \\
\hline kujawsko-pomorskie & 49,8 & 57,1 & 42,2 \\
\hline lubelskie & 45,7 & 53,7 & 37,4 \\
\hline lubuskie & 47,7 & 54,4 & 40,0 \\
\hline łódzkie & 50,4 & 55,0 & 45,6 \\
\hline małopolskie & 51,7 & 57,0 & 46,2 \\
\hline mazowieckie & 51,9 & 55,1 & 48,6 \\
\hline opolskie & 52,1 & 58,3 & 44,1 \\
\hline podkarpackie & 45,3 & 53,8 & 36,0 \\
\hline podlaskie & 49,5 & 54,7 & 42,7 \\
\hline pomorskie & 53,3 & 59,9 & 46,4 \\
\hline śląskie & 53,4 & 58,9 & 47,3 \\
\hline świętokrzyskie & 46,0 & 52,9 & 38,5 \\
\hline warmińsko-mazurskie & 45,8 & 55,2 & 36,7 \\
\hline wielkopolskie & 55,9 & 61,9 & 49,8 \\
\hline zachodniopomorskie & 46,4 & 53,5 & 38,5 \\
\hline
\end{tabular}

Źródło: opracowanie własne na podstawie: GUS (2020, 11 października) 
Rycina 3. Stopa bezrobocia w Polsce i województwie podkarpackim w latach 2006-2019

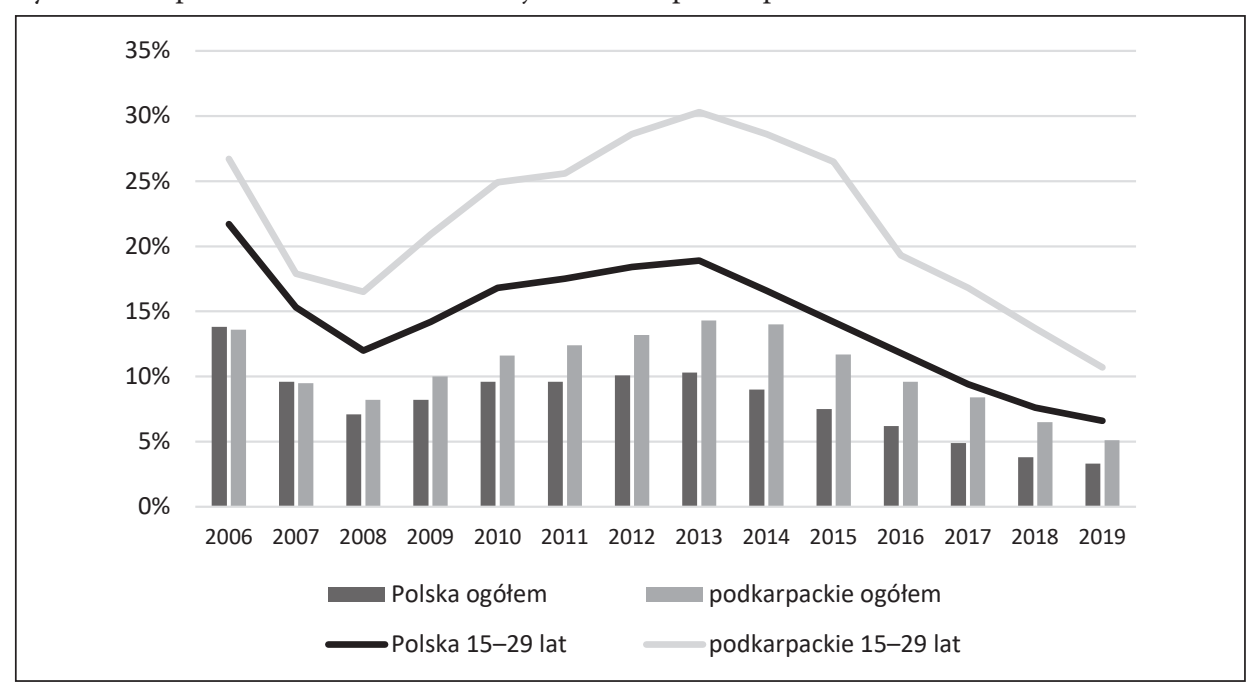

Źródło: opracowanie własne na podstawie: GUS (2020, 7 października)

W grupie osób aktywnych zawodowo w województwie podkarpackim duży odsetek stanowią osoby bezrobotne. Stopa bezrobocia w województwie w roku 2019 była wyższa niż średnio w kraju (5,1\% wobec 3,3\%,), podobnie w grupie osób w wieku 15-29 lat, dla której przedstawione wartości należy podwoić (wynoszą one odpowiednio 10,7\% wobec $6,6 \%$ ). Pozytywnie należy ocenić spadek wartości charakteryzowanego wskaźnika w ostatnich latach (rycina 3), przy czym w całym przedstawionym okresie wartość ta w województwie podkarpackim spadła w odniesieniu do młodych osób 2,5-krotnie, podczas gdy w Polsce 3,3-krotnie. Zaznaczyć jednak należy, że w 2020 r., w wyniku pandemii COVID-19, stopa bezrobocia (ogółem) ponownie wzrosła - w październiku wyniosła na Podkarpaciu 8,9\% i średnio 6,1\% w kraju, co oznacza wzrost odpowiednio o 1,3 pp. i 1,1 pp. wobec analogicznego okresu poprzedniego roku.

Analizując sytuację w województwie podkarpackim na tle pozostałych województw, ponownie należy ocenić ją jako bardzo niekorzystną. Podkarpacie jest jednym z dwóch województw o najwyższym wskaźniku bezrobocia, widocznie odróżniających się sytuacją $\mathrm{w}$ tym kontekście od pozostałych regionów, co dotyczy również młodych osób $(\text { rycina } 4)^{1}$.

Szczegółowa analiza danych dotyczących województwa podkarpackiego pokazuje, że w 2019 r. ze 109137 przybyłych bezrobotnych (napływ) aż 47\% były to osoby do 30 roku życia (51 285), z czego niemal 36 tys. stanowiły osoby rejestrujące się po raz kolejny. W grupie młodych bezrobotnych przeważały osoby do 25 roku życia (59,26\%) (Konieczny, 2019).

Większość młodych osób rejestruje się jako bezrobotna więcej niż jeden raz, jednocześnie spora część, bo ok. 30\% odmawia przyjęcia pracy, nie potwierdza w urzędzie gotowości do pracy lub rezygnuje z pracy dobrowolnie (Konieczny, 2019). Świadczy to o pasywności dużej części z nich w wyjściu ze statusu bezrobotnego. Taka postawa

\footnotetext{
${ }^{1}$ Brak danych dotyczących województwa lubuskiego.
} 
Rycina 4. Stopa bezrobocia wśród osób w wieku 15-29 lat w 2019 r. według województw

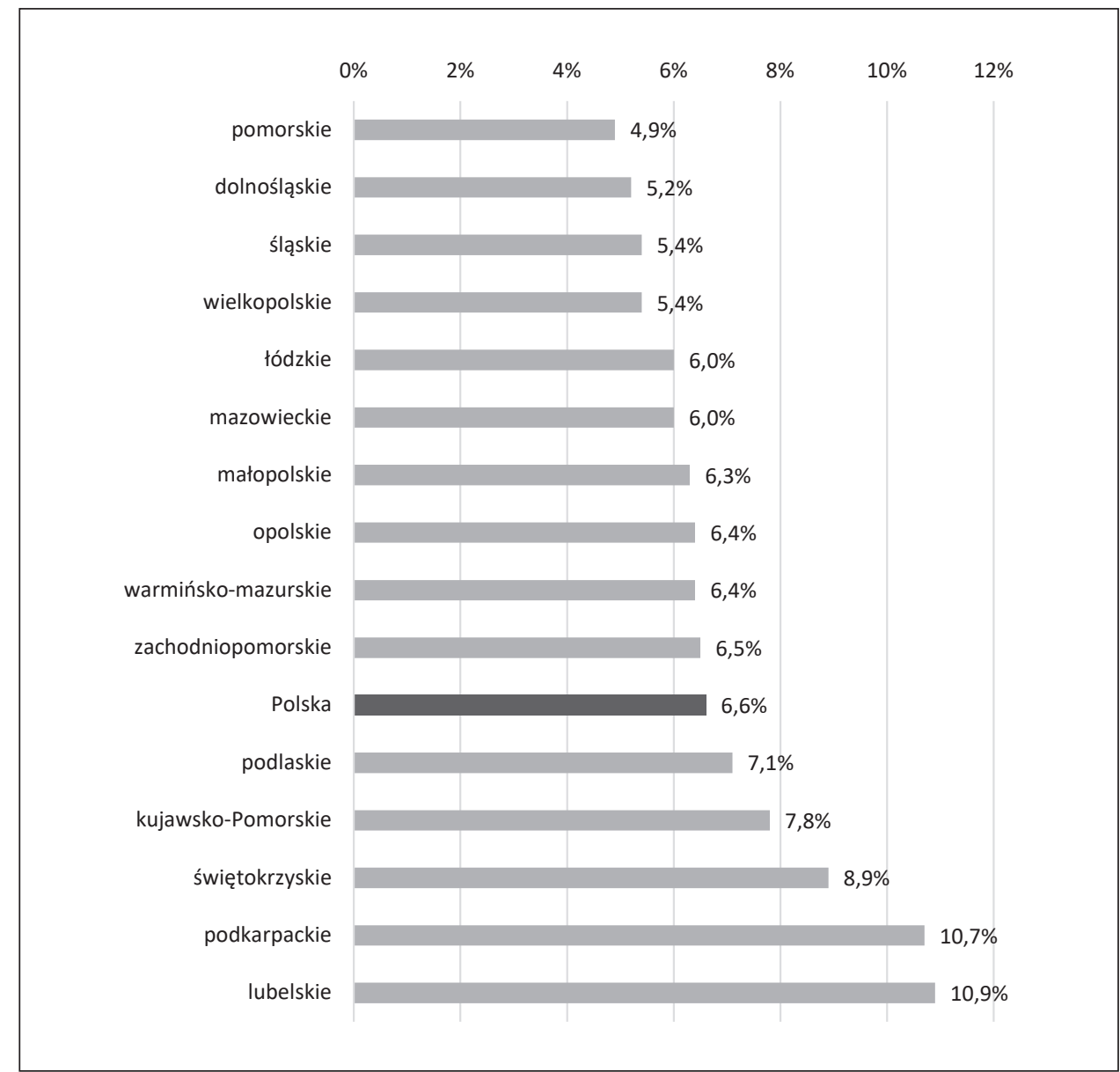

Źródło: opracowanie własne na podstawie: GUS (2020, 5 października)

sprzyja włączeniu do grupy NEET. Udział tej kategorii wśród osób w wieku 15-29 lat w województwie podkarpackim jest jednym z najwyższych w Polsce i znacząco przekracza średnią dla kraju - w 2019 r. wyniósł 15,1\% wobec 12,0\%. Jest również wyższy niż średnia dla Unii Europejskiej, która wyniosła 12,5\%. Uwzględniając dalszy podział na grupy wiekowe, obserwuje się niższą wartość wskaźnika w grupie 15-24 lata, przede wszystkim ze względu na chęć kontynuowania nauki - w 2019 r. udział NEET w tej grupie wiekowej wyniósł 10,9\%.

Udział osób biernych zawodowo, nieuczestniczących w jakichkolwiek formach nauki i szkoleń, w grupie osób w wieku 15-29 lat w województwie podkarpackim był wyższy niż w Polsce i Unii Europejskiej (28 krajów) przez cały okres członkostwa Polski w UE - średnio o 3,9 pp. (rycina 5). Zaakcentować należy, że średnia dla Polski przez większość okresu jej członkostwa w UE, za wyjątkiem pierwszych lat, jest korzystniejsza niż średnia dla UE. Po początkowym spadku odsetek NEET zaczął wzrastać, co przypuszczalnie stanowiło rezultat kryzysu w gospodarce światowej, jednak zarówno na poziomie unijnym, jak 
Rycina 5. Udział NEET wśród osób w wieku 15-29 lat w województwie podkarpackim na tle Polski i UE w latach 2005-2019

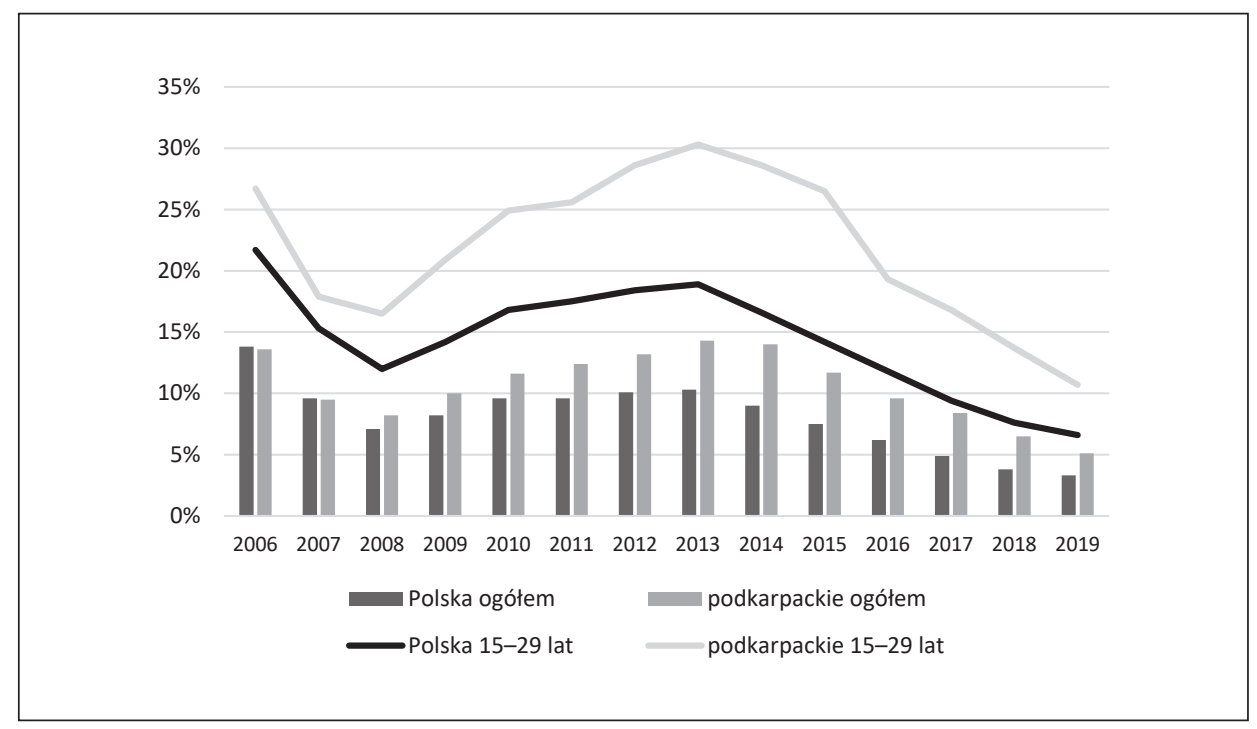

Źródło: opracowanie własne na podstawie: Eurostat (2020, 5 października)

i krajowym wahania nie były tak znaczące jak w województwie. W latach 2013-2015 różnica pomiędzy poziomem unijnym i krajowym a poziomem wojewódzkim wynosiła 6 pp.

Analiza danych statystycznych w konsekwencji skłania do sformułowania dwóch zasadniczych pytań:

1. Czy pracodawcy stwarzają warunki do poprawy sytuacji młodych osób na rynku pracy i wyrażają wolę zatrudniania ich?

2. Czy młode osoby charakteryzują się przedsiębiorczością, która umożliwiałaby im poprawę swojej sytuacji na rynku pracy?

Niewątpliwie istotne są pytania dotyczące uwarunkowań instytucjonalnych, zagadnienia te wykraczają jednak poza ramy niniejszego opracowania.

Odnosząc się do ofert pracy, należy zauważyć ich systematyczny wzrost na podkarpackim rynku pracy przypadający na 1 tys. bezrobotnych młodych osób - z 14,7 w $2006 \mathrm{r}$. do 30,2 w 2015 r. Po tym okresie wzrost ten był jeszcze dynamiczniejszy i wartość ta wyniosła 65,2, aby w 2019 r. spaść do 53,2. Pozytywne zmiany wynikały z większego wzrostu lub mniejszego spadku liczby ofert pracy niż liczby bezrobotnych. Spadek wartości w ostatnim roku analizy wynikał z większego spadku liczby ofert pracy niż liczby bezrobotnych. Wzrost wartości dotyczył również całego kraju, jednak średnia dla kraju była 2- lub 3-krotnie wyższa niż dla województwa podkarpackiego, a od 2017 r. niemal lub ponad 4-krotnie i w 2019 r. wyniosła 227,5 oferty na 1 tys. bezrobotnych osób w wieku 15-29 lat. Wynikało to ze zdecydowanie korzystniejszych zmian dotyczących liczby oferowanych miejsc pracy niż liczby bezrobotnych, z wyjątkiem ostatniego roku, w którym nastąpił większy spadek liczby ofert niż liczby bezrobotnych.

Podobnie jak liczba ofert pracy w województwie wzrastała liczba nowo utworzonych miejsc pracy (rycina 6). Od 2008 r, od którego są udostępniane dane, z wyjątkiem roku 2009 , była ona wyższa niż liczba likwidowanych miejsc. Jednak w ostatnim roku analizy 
Rycina 6. Liczba nowo utworzonych i likwidowanych miejsc pracy w województwie podkarpackim

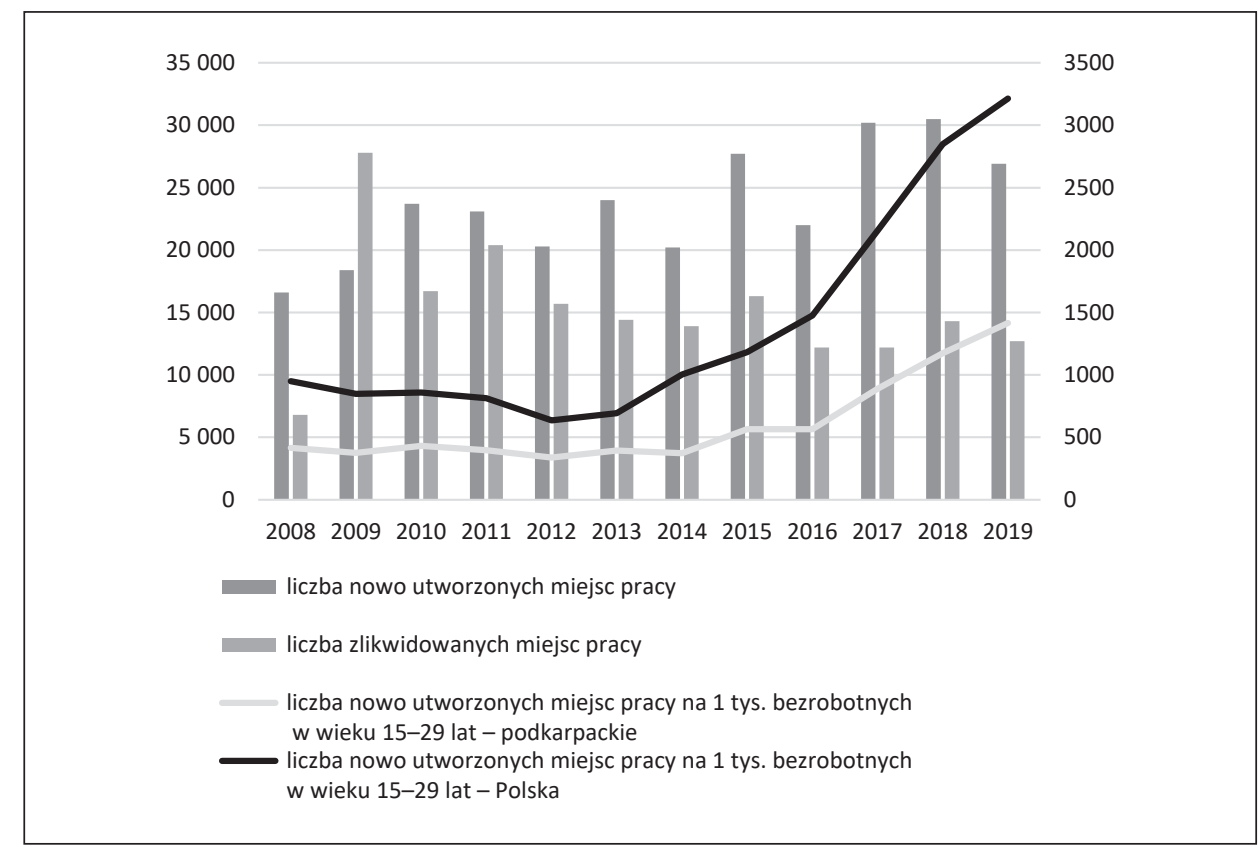

Źródło: opracowanie własne na podstawie: GUS (2020, 15 października)

zmniejszyła się podaż nowych miejsc, zmniejszeniu uległa równocześnie liczba likwidowanych miejsc - utworzono ich 16,6 tys., zlikwidowano natomiast 12,7 tys. Uwzględniając popyt na pracę w postaci liczby bezrobotnych młodych osób, należy zauważyć wzrost liczby nowych miejsc pracy w przeliczeniu na 1 tys. osób bezrobotnych w wieku 15-29 lat - z 415 do 1415,18 w 2019 r. Wartość ta kształtowała się korzystniej przeciętnie w kraju - wzrosła odpowiednio z 950,8 do 3213,3. Oznacza to, że w województwie podkarpackim występują mniejsze możliwości skorzystania z potencjału bezrobotnych młodych osób, co stanowi m.in. przyczynę emigracji w poszukiwaniu pracy i ma konsekwencje zarówno dla jednostki, jak i dla regionu.

Zapotrzebowanie na pracowników związane jest przede wszystkim z fluktuacją pracowników bądź niedostosowaniem ich kwalifikacji do potrzeb pracodawców. Poszukuje się zwłaszcza specjalistów, osób z wykształceniem wyższym, posiadających doświadczenie zawodowe (WUP, 2020); nie są to zatem kryteria, które spełnia większość młodych osób.

Jednocześnie młode osoby nie deklarują predyspozycji przedsiębiorczych na wysokim poziomie, które pozwoliłyby im na zwiększenie szans na rynku pracy. Dotychczasowe badania autorki opracowania umożliwiają stwierdzenie, że swoją dyspozycję do przedsiębiorczości zdecydowana większość badanych młodych osób ocenia na poziomie co najmniej przeciętnym (Mazurkiewicz, 2020). Uzupełnieniem sformułowanych spostrzeżeń są wyniki własnych badań dotyczących orientacji w karierze młodych osób, które pozwolą wyeksponować preferencje dotyczące przedsiębiorczości. Badania nie stanowią zasadniczego przedmiotu dociekań w niniejszym opracowaniu, umożliwią jednak uzyskanie odpowiedzi na pytanie dotyczące skłonności młodych osób do podejmowania aktywności w celu poprawy swojej sytuacji na rynku pracy. 
Przedsiębiorcze predyspozycje młodych osób - wyniki badań własnych

Przeprowadzone badania własne stanowiły część większych badań dotyczących postaw przedsiębiorczych w zarządzaniu karierą zawodową. Kwestionariusz, z którego skorzystano w niniejszym opracowaniu, stanowi fragment narzędzia przygotowanego do realizacji kompleksowych badań. Orientacja w karierze, będąca zestawem postrzeganych przez jednostkę talentów i zdolności, podstawowych wartości, motywów i potrzeb związanych z karierą (Schein, 2007), zmierzona została przy zastosowaniu opracowanej przez M. Igbaria i J.J. Baroudi (1993) skróconej wersji Kwestionariusza orientacji w karierze (Career Orientation Inventory - COI), autorstwa Scheina (1985). Kwestionariusz zawiera 25 stwierdzeń, z czego 15 dotyczy znaczenia każdego z zagadnień związanych z karierą (ocenianych w skali od 1 - „bez znaczenia” do 5 - „o zasadniczym znaczeniu”), a kolejne 10 odnosi się do preferencji wobec kariery ocenianych w skali od 1 - „całkowicie się nie zgadzam” do 5 - „całkowicie się zgadzam”.

Do badania, które zrealizowano w 2019 r. metodą ankietową, zaproszono 303 studentów z 3 podkarpackich szkół wyższych, studiujących na drugim stopniu, na kierunkach ekonomia i zarządzanie. Zwrotnie otrzymano 267 (88,12\%) kompletnie wypełnionych kwestionariuszy. Wśród respondentów przeważały kobiety, które stanowiły ponad 83\% badanych. Przedstawione proporcje wyznaczone według kryterium płci odpowiadają strukturze studentów i wynikają ze specyfiki kierunków studiów, na których przeprowadzono badania. Średnia wieku respondentów wyniosła 24 lata, a przeciętne doświadczenie zawodowe - półtora roku (1,54 lat), przy czym ponad połowa osób $(55,1 \%)$ nie podjęła do momentu przeprowadzania badań jakiejkolwiek aktywności zawodowej. Szczegółową charakterystykę próby badawczej zawiera tabela 2 .

Tabela 2. Charakterystyka próby badawczej

\begin{tabular}{|l|c|}
\hline \multicolumn{1}{|c|}{ Wyszczególnienie } & Wartość \\
\hline $\begin{array}{l}\text { Płeć } \\
\text { mężczyźni }\end{array}$ & $17 \%$ \\
kobiety & $83 \%$ \\
\hline Wiek & 24 lata \\
\hline Doświadczenie zawodowe & 1,54 lat \\
\hline Stan cywilny & \\
$\quad$ żonaty/zamężna & $11,6 \%$ \\
stan wolny & $88,4 \%$ \\
\hline Miejsce zamieszkania & \\
miasto & $40,4 \%$ \\
wieś & $59,6 \%$ \\
\hline
\end{tabular}

Źródło: opracowanie własne na podstawie badań

Poszczególne preferencje zostały wyliczone jako średnie wartości z odpowiedzi udzielonych na stwierdzenia określające orientację w karierze (rycina 7).

Wyniki badań dowodzą, że respondenci oceniają swoje umiejętności i motywację w zakresie przedsiębiorczej kreatywności na poziomie 3,81. Silniej do rozwiązywania niestandardowych problemów, inicjowania zmian, podejmowania skalkulowanego ryzyka, stawania się niezależnym dążą mężczyźni (odczuwający jednocześnie silniejszą potrzebę 
Rycina 7. Średnie odpowiedzi respondentów dotyczące orientacji w karierze

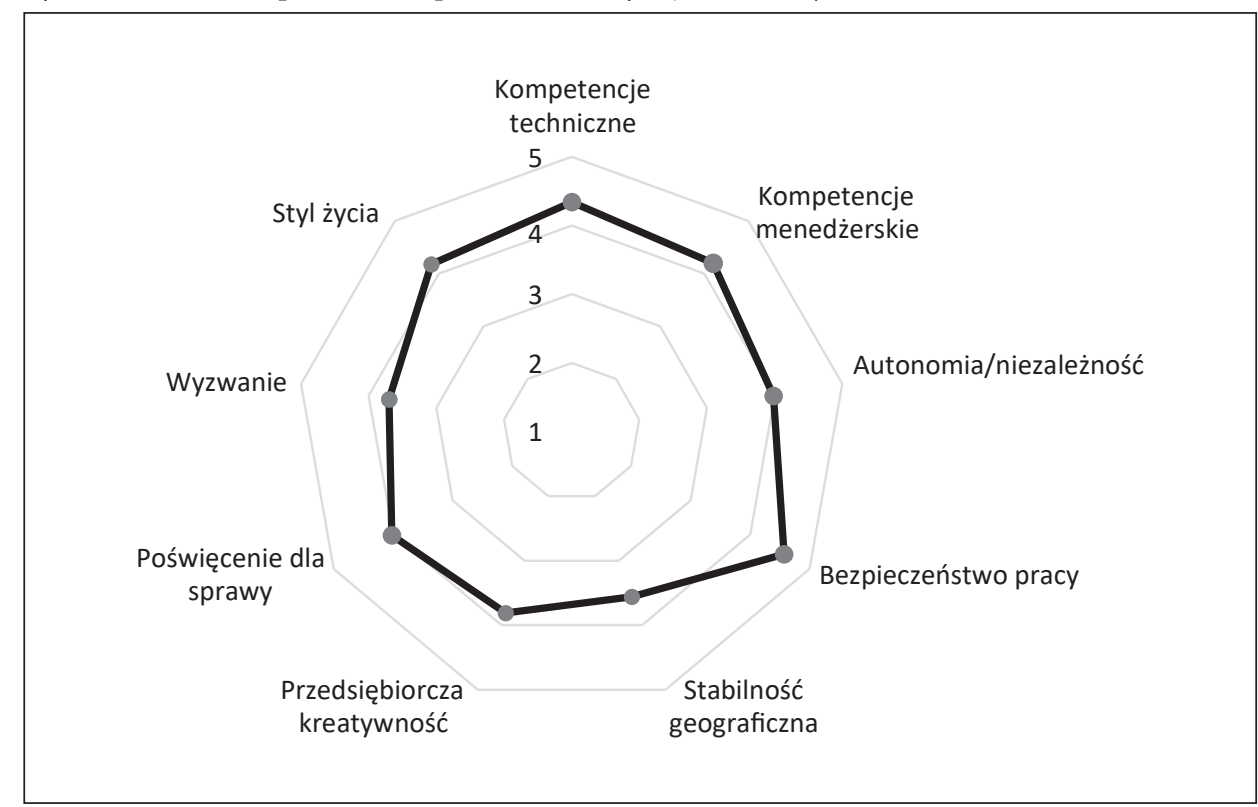

Źródło: opracowanie własne na podstawie badań

autonomii) - w tej grupie średni wynik wyniósł 3,96, podczas gdy kobiety potrzebę twórczości i kreowania nowości oceniły średnio na 3,78.

$\mathrm{Na}$ tle pozostałych kotwic kariery oraz potrzeby przedsiębiorczego działania na rynku pracy otrzymany wynik ocenić należy jako mało satysfakcjonujący - respondenci byli w największym stopniu zainteresowani pracą, która zapewnia stabilność zatrudnienia (średnia 4,57). W dalszej kolejności deklarowali znaczenie stania się ekspertem w określonej dziedzinie, potwierdzenie własnego mistrzostwa (średnia dla kompetencji technicznych wyniosła 4,34 ). Mniejsze znaczenie miały dla nich kompetencje menedżerskie (średnia 4,20) oraz styl życia, oceniony na zbliżonym poziomie (średnia 4,18). Osoby uczestniczące w badaniach były w dalszej kolejności zorientowane na aktywność użyteczną społecznie - udzielanie pomocy i wsparcia innym (średnia 4,02) oraz niezależne działanie, bez ograniczeń związanych z biurokracją i autokratycznym stylem zarządzania (średnia 3,98).

W mniejszym stopniu respondenci zainteresowani byli rywalizacją, podejmowaniem ryzyka, poszukiwaniem nowych rozwiązań, pokonywaniem barier i ograniczeń (średnia 3,70 ), co jest charakterystyczne dla osób przedsiębiorczych i jednocześnie istotne w trudnej sytuacji na rynku pracy. Jako atut uczestniczących w badaniach wskazać należy na deklarowaną mobilność, gotowość do przemieszczania się - stabilność geograficzna do działania motywowała badanych w najmniejszym stopniu (średnia 3,56).

\section{Zakończenie}

Sytuacja na rynku pracy jest zależna od wielu czynników zmiennych w czasie, mających charakter społeczny, demograficzny, gospodarczy czy prawny. Spostrzeżenie to potwierdzają zmiany na tym rynku, także w ujęciu regionalnym. W odniesieniu do młodych 
osób, uwzględniając okres przyjęty w niniejszym opracowaniu (od 2006 r.), po poprawie sytuacji stanowiącej rezultat przystąpienia Polski do Unii Europejskiej, od 2008 r. odnotowano negatywne zmiany wynikające ze światowego kryzysu gospodarczego, związane przede wszystkim ze wzrostem poziomu bezrobocia. Sytuacja na rynku ulegała systematycznej poprawie od 2013 r. - zauważalny jest wtedy wzrost liczby zgłaszanych przez pracodawców ofert pracy, zmniejszanie się stopy bezrobocia. Pogorszenie tej sytuacji, w tym zwłaszcza wzrost stopy bezrobocia, obserwuje się w 2020 r. jako konsekwencję pandemii COVID-19.

$\mathrm{Na}$ tle kraju sytuacji na podkarpackim rynku pracy nie można jednak ocenić jako korzystnej dla młodych osób - województwo podkarpackie cechują: najniższy wskaźnik zatrudnienia, wysoka stopa bezrobocia oraz niewielka liczba ofert pracy przypadająca na 1 tys. bezrobotnych młodych osób. Dodatkowo pracodawcy poszukują przede wszystkim specjalistów, co uniemożliwia wykorzystanie potencjału młodych, niedoświadczonych jeszcze osób, nieposiadających dogłębnej wiedzy w określonej dziedzinie. Jednocześnie wyniki przeprowadzonych badań własnych nie dostarczają pozytywnych wniosków dotyczących postaw badanych osób - nie oceniają one swoich zdolności, motywów i potrzeb związanych z przedsiębiorczością satysfakcjonująco wysoko, uwzględniając wymagania podkarpackiego rynku pracy.

Wśród rozwiązań, które przyczynią się do poprawy sytuacji młodych osób, zwiększą ich szanse na zatrudnienie, wymienić należy szkolenia poświadczające nabycie umiejętności adekwatnych do potrzeb zgłaszanych przez pracodawców. Powinny być one skierowane zwłaszcza do osób z grupy NEET. Szkolenia powinny również umożliwiać doskonalenie kompetencji miękkich, oczekiwanych od pracowników.

Wskazuje się również na potrzebę monitoringu losów absolwentów w celu dostosowania programu kształcenia do potrzeb rynku pracy, z uwzględnieniem opinii pracodawców, instytucji otoczenia biznesu oraz instytucji rynku pracy (Centrum Edukacji i Aktywizacji Zawodowej Osób Niepełnosprawnych w Rzeszowie, Fundacja Aktywizacja, RARR, 2016).

Natomiast w celu zwiększenia przedsiębiorczości pracujących młodych osób niezbędne staje się motywowanie ich do kreatywności. Cenne jest skorzystanie z wiedzy i umiejętności menedżerów w zakresie zarządzania zasobami ludzkimi, gdyż kompetencje i wsparcie przełożonych stanowią warunek efektywności przedsiębiorczych działań w organizacji. Kultura organizacyjna powinna sprzyjać zaangażowaniu się pracowników.

Przeprowadzone badania własne dotyczyły samooceny respondentów, wskazują na ich intencje, motywacje niezbędne do podjęcia działania. Nie koncentrują się na rezultatach tego działania, co stanowi ich ograniczenie. Badania zostały przeprowadzone na małej próbie z województwa podkarpackiego, co nie stanowi podstawy do uogólniania uzyskanych wyników.

\section{Literatura}

References

Bańka, A. (2007). Poradnictwo zawodowe w kształtowaniu przedsiębiorczości, kapitału kariery oraz zdolności zatrudnieniowej młodzieży. W: A. Biela (red.), Nauka pracy, doradztwo zawodowe i przedsiębiorczość młodzieży. Warszawa: Kancelaria Senatu, 52-64. 
Barone, C., Schizzerotto, A. (2011). Career mobility, education and intergenerational reproduction in five European societies. European Societies, 13, 331-346.

Bell, D.N.F., Blanchflower, D.G. (2011a). Young People and the Great Recession. Oxford Review of Economic Policy, 27, 241-267. doi: 10.1093/oxrep/grr011

Bell, D.N.F., Blanchflower, D. G. (2011b). Youth unemployment in Europe and the United States. Nordic Economic Policy Review, 1, 11-37.

Blanchflower, D.G. (2010). The wellbeing of the young. Pozyskano z: https://sites.dartmouth.edu/blanchflower/other-papers/files/2020/08/bjir-youth-attitudes-draft.pdf

Blanchflower, D.G., Oswald, A.J. (2011). International Happiness: A New View on the Measure of Performance. Academy of Management Perspectives, 25(1), 6-22. doi: 10.5465/AMP.2011.59198445

Braziene, R., Merkys, G., Mikutaviciene, I. (2014). Employers' Expectations and Young Workers Selection Criteria in Lithuania. Social Sciences, 4(86), 62-69. doi: 10.5755/j01.ss.86.4.9226

Broszkiewicz, W. (2010). Kapitał kulturowy młodego pokolenia Polski wspótczesnej. Studium na przykładzie wybranych społeczności Podkarpacia. Rzeszów: Wydawnictwo Uniwersytetu Rzeszowskiego.

Centrum Edukacji i Aktywizacji Zawodowej Osób Niepełnosprawnych w Rzeszowie, Fundacja Aktywizacja, RARR. (2016). Rekomendacje w zakresie aktywizacji osób młodych znajdujących się w najtrudniejszej sytuacji na rynku pracy w województwie podkarpackim. Pozyskano z: https://efs. mrpips.gov.pl/_data/assets/pdf_file/0016/9124/0008_podkarpackie-rekomendacje.pdf

Eurostat. (2020, 5 października). Pozyskano z: https://appsso.eurostat.ec.europa.eu/nui/show.do?dataset=edat_lfse_22\&lang=en

FutureLab Europe. (2013). Europe's lost generation? Young Europeans' perspectives on the crisis. Belgium: Pozyskano z: https://futurelabeurope.files.wordpress.com/2016/09/futurelab_europe_report_ lost_generation_2013.pdf

Gallie, D., Paugam, S. (2000). Welfare regimes and the experience of unemployment in Europe. Oxford: Oxford University Press.

Genda, Y., Kondo, A., Ohta, S. (2010). Long-Term Effects of a Recession at Labor Market Entry in Japan and the United States. Journal of Human Resources, 45(1), 157-196.

GUS. (2020, 15 października). Dane z BDL. Pozyskano z: https://bdl.stat.gov.pl/BDL/dane/podgrup/ temat

GUS. (2020, 11 października). Dane z BDL. Pozyskano z: https://bdl.stat.gov.pl/BDL/dane/podgrup/ temat

GUS. (2020, 8 października). Dane z BDL. Pozyskano z: https://bdl.stat.gov.pl/BDL/dane/podgrup/temat

GUS. (2020, 7 października). Dane z BDL. Pozyskano z: https://bdl.stat.gov.pl/BDL/dane/podgrup/temat

GUS. (2020, 5 października). Dane z BDL. Pozyskano z: https://bdl.stat.gov.pl/BDL/dane/podgrup/ temat

GUS. (2010). Wejście ludzi młodych na rynek pracy. Pozyskano z: https://stat.gov.pl/cps/rde/xbcr/gus/ PUBL_Wejscie_ludzi_mlodych_na_rynek_pracy.pdf

Igbaria, M., Baroudi, J.J. (1993). Short form measure of career orientations: a psychometric evaluation. Journal of Management Information Systems, 10(2), 131-154. doi: 10.1080/07421222.1993.11518003

Jakimiuk, B. (2017). Bezrobocie wśród polskiej młodzieży i jego dynamika. Annales Universitatis Mariae Curie-Skłodowska Lublin, XXX(4), 193-203. doi: 10.17951/j.2017.30.4.193

Kahn, L.B. (2010). The Long-term Labour Market Consequences of Graduating from College in a Bad Economy. Labour Economics, 17(2), 303-316.

Komisja Europejska. (2020, 5 października). Europejski semestr - zestawienie informacji tematycznych. Zatrudnienie ludzi młodych. Pozyskano z: https://ec.europa.eu/info/sites/info/files/file_import/european-semester_thematic-factsheet_youth_employment_pl.pdf

Konieczny, M. (2019). Osoby młode na rynku pracy w województwie podkarpackim w okresie I-XII 2019 r. Rzeszów: WUP. Pozyskano z: https://wuprzeszow.praca.gov.pl/-/10962977-osoby-mlode-na-rynku-pracy-w-wojewodztwie-podkarpackim-w-okresie-i-xii-2019-r- 
Koptiew, D. (2014). Sytuacja grup defaworyzowanych na rynku pracy w Polsce - osoby młode versus osoby starsze. Przedsiębiorczość i Zarządzanie, 15, 233-247.

Krause, E. (2016). Zjawisko NEET, czyli o młodzieży trzy razy nic. Problemy Profesjologii, 2, 67-81.

Mackenzie Davey, K., Arnold, J. (2000). A multi-method study of accounts of personal change by graduates starting work: Self-ratings, categories and women's discourses. Journal of Occupational and Organizational Psychology, 73, 461-486. doi: 10.1348/096317900167164

Mazurkiewicz, A. (2020). Badanie postaw przedsiębiorczych studentów ekonomii. Przedsiębiorczość Edukacja [Entrepreneurschip - Education], 16(2), 113-127. doi: 10.24917/20833296.162.9

Mroz, T.A., Savage, T.H. (2006). The Long-Term Effects of Youth Unemployment. Journal of Human Resources, 41(2), 259-293.

Pańków, M. (2012). Młodzi na rynku pracy. Raport z badania. Warszawa: Wydawnictwo Instytutu Spraw Publicznych.

Piecuch, T., Piecuch, M. (2014). Analiza sytuacji młodych ludzi na rynku pracy - rozważania teoretyczne i badania empiryczne. Modern Management Review, 21(4), 175-186. doi: 10.7862/rz.2014.mmr.54

Rybicka, K. (2014). Bezrobocie młodzieży w Polsce. Studia Ekonomiczne, 197, 195-210.

Schein, E.H. (1985). Career Anchors: Discovering your Real Values. San Diego: University Associates.

Schein, E.H. (2007). Career anchors revisited: implications for career development in the 21st century. Career Management, NHRD Journal, 1(4), 27-33. doi: 10.5465/AME.1996.3145321

Wiatrowski, Z. (2009). Dorastanie, dorosłość i starość człowieka w kontekście działalności i kariery zawodowej. Radom: Instytut Technologii Eksploatacji - PIB.

Mazowieckie Obserwatorium Rynku Pracy. Wojewódzki Urząd Pracy w Warszawie. (2014). Wsparcie młodych osób na mazowieckim rynku pracy. Pozyskano z: http://obserwatorium.mazowsze.pl/pliki/files/Raport_finalny_z_badania_NEET_okl.pdf

WUP. (2020). Zapotrzebowanie na zawody oraz kwalifikacje i kompetencje na lokalnych rynkach pracy w województwie podkarpackim - edycja 2019. Pozyskano z: https://wuprzeszow.praca.gov.pl/ documents/60111/11864198/Zapotrzebowanie\%20na\%20zawody_2019_raport\%20wojew\%C3\% B3dzki.pdf/8e6bff5f-09f9-48d1-a1c5-18cac9ea0fa0?t=1585129444000

Anna Mazurkiewicz, dr, adiunkt w Instytucie Ekonomii i Finansów Uniwersytetu Rzeszowskiego. Jej zainteresowania naukowe koncentrują się wokół zagadnień związanych z zarządzaniem pracownikami utalentowanymi i zarządzaniem karierą. Jest autorką publikacji naukowych z zakresu zarządzania, dotyczących zwłaszcza znaczenia kapitału ludzkiego we współczesnej organizacji.

Anna Mazurkiewicz, PhD, assistant professor at the Institute of Economics and Finance at the University of Rzeszów. Her research interests focus on issues related to talented staff management and career management. She is the author of several academic publications on management, especially regarding the importance of human capital in contemporary organisations.

ORCID: https://orcid.org/0000-0003-2764-284X

\section{Adres/Address:}

Uniwersytet Rzeszowski

Kolegium Nauk Społecznych

Instytut Ekonomii i Finansów

Katedra Ekonomiki i Zarządzania

ul. Ćwiklińskiej 2

35-601 Rzeszów, Poland

e-mail: annam@ur.edu.pl 